\title{
ARTICLES
}

\section{Traditional medicine trade in vulture parts in northern Nigeria}

\author{
Yohanna Saidu ${ }^{1}$ and Ralph Buij ${ }^{2 *}$
}

\author{
${ }^{1}$ National Park Service Headquarters; Private Mail Bag 0258, Umaru Musa Yar’adua \\ Express way, Garki, Abuja, Nigeria \\ ${ }^{2}$ Institute of Environmental Sciences, Leiden University, PO Box 9518, 2300 RA \\ Leiden, The Netherlands \\ * Corresponding author: ralph.buij@gmail.com
}

\section{Summary}

We report findings on the vulture trade in northern Nigeria, where it is commonly practised especially to supply the traditional medicine industry. We administered an open-ended questionnaire to 113 traditional, predominantly Hausa medicinal traders in 39 markets within eight states in northern Nigeria. Of the interviewed traders, $78 \%$ only had feathers of vultures on display in their stalls, $11 \%$ also offered vulture heads and $4.4 \%$ offered entire vultures; $40 \%$ of traders sold vultures for spiritual healing and 25\% sold vultures for consumption. Forty-three percent of traders were supplied most often from vulture populations inside Nigeria and $48 \%$ were principally supplied from other countries in the region, as far west as Benin and east to Sudan. Increased prices for parts during the past 10 years reflected similar, or perhaps increasing, demand but lower availability of vultures. Hooded Vulture (Necrosyrtes monachus) was the commonest species traded with $90 \%$ of parts belonging to this species. Vultures sold in stalls had been killed using agricultural chemicals, shotguns, traps, and ground tobacco powder. Urgent and drastic conservation measures are needed to prevent further exploitation of critically endangered vultures in Nigeria and surrounding countries. 


\section{Introduction}

In sub-Saharan West Africa, major declines of the populations of the four large vulture species (Rüppell's Griffon Gyps rueppellii, African White-backed Vulture Gyps africanus, Lappet-faced Vulture Torgos tracheliotos, White-headed Vulture Trigonoceps occipitalis) and, to a lesser extent, the two smaller vultures (Hooded Vulture Necrosyrtes monachus and Egyptian Vulture Neophron percnopterus) have been reported during the past four decades (Rondeau and Thiollay 2004, Thiollay 2001, 2006, 2007). Rondeau and Thiollay (2004) listed reduced carcass availability, poisoning, slaughter for traditional medicine, hunting, electrocution and collision, disturbance, and exposure to contaminants as possible causes for the West African vulture decline. Evidence suggests that persecution of vultures for body parts serving witchcraft purposes in Nigeria has long taken a toll on populations (Cook \& Mundy 1980, Nikolaus 2001), together with the trade of smoked vulture meat for food in this country (G. Rondeau in Thiollay 2006). Most authors documenting animal parts used in traditional medicine in Nigeria recorded the use of vultures for traditional medicine
(Adeola 1992, Sodeinde and Soewu 1999, Nikolaus 2001, Igoli et al. 2005, Soewu 2008), notably in the southwest of the country. Still, little up-to-date, published information on the extent of the trade in vulture parts for traditional medicine in Nigeria is available, despite the potentially large impact that persecution for food and witchcraft may have on vulture populations (Beilis \& Esterhuizen 2005, Mander et al. 2007).

Here, we report on the use of vultures to supply the traditional medicine trade in northern Nigeria. We aimed to ascertain (1) the extent of trade in vulture parts for medicinal purposes in northern Nigeria; (2) the origin of the vultures traded on Nigerian markets; and (3) the origin of traders, medicinal values attributed to vulture parts, and their price.

\section{Methods}

Data collection was through openended questionnaires administered to 113 traditional medicine traders who offered animal products within the eight States in northern Nigeria (Table 1 and Appendix for market locations). The states covered in the survey cut across the three geopolitical zones in the northern part of the country, which are North-East, 
North-West and North-Central. The term 'traditional medicine' is used here to refer to the use of wild animal parts to treat physiological or psychological ailments, and their application for ceremonial, religious or spiritual purposes associated with healing. These traditional medicine dealers are commonly known as "Yan-Shinfida" in the dominant Hausa language of northern Nigeria, a general term for herbalists who sell medicinal plants and animal parts, usually by displaying such items openly in stalls or on mats (Ibrahim et al. 2010). Traders were interviewed from January to September 2011. Most of the markets in villages and towns surveyed were located along the major roads for easy accessibility to customers and goods. Before commencing the survey, permission was sought from the chairman of the traditional medicine dealers association. Information was collected on the selling price of vulture carcasses and their parts (i.e. head, feathers, legs), the tribe involved in the trade, the species on offer, their country of origin, the medicinal value attributed to vultures, and the method used to harvest the vultures. Questionnaires were administered and interpreted in Hausa by local interpreters to allow effective communication and build the trust needed to obtain the information.

Table 1: Market locations of 113 traders in traditional medicine interviewed in the eight states covered in the survey. The number of markets per state is indicated.

\begin{tabular}{lc}
\hline State of Survey & Markets \\
\hline Barno State & 19 \\
Bauchi State & 6 \\
Niger State & 19 \\
Traba State & 9 \\
Yobe State & 18 \\
Adamawa State & 26 \\
Kaduna State & 10 \\
Katsina State & 6 \\
\hline
\end{tabular}




\section{Results}

\section{Traders}

The traditional medicine traders $(n=$ the traders, $90.3 \%$ inherited the trade 113) were predominantly of the from their parents and $8 \%$ learnt the Hausa tribe (67.3\% of respondents), trade from people outside their Fulani (10.6\%), and eleven other family. The majority of traders who minor tribes, of which Abewa, provided details started the trade Bagobiri, Kanuri, and Zabarma were more than 20 years ago (Table 2). most common (2-3.5\% of total). Of

Table 2: The total duration of occupation in the traditional medicine trade by 113 traders in northern Nigeria.

\begin{tabular}{lc}
\hline Duration in trade & Percentage \\
\hline 6-10 years & 15.0 \\
11-15 years & 14.2 \\
16-20 years & 4.4 \\
$>$ 20 years & 21.2 \\
No response & 45.1 \\
\hline
\end{tabular}

Medicinal value attributed to vulture parts

Of the interviewed traders, $78 \%$ had only feathers of vultures on display in their stalls, $11 \%$ also offered vulture heads and $4.4 \%$ offered entire vultures mostly for their meat, while $7.1 \%$ had no vultures or their parts in their stalls. No vulture eggs or nests were recorded in the stalls, according to traders as a result of the difficulty in obtaining these items. Forty percent of traders sold vulture parts for spiritual healing and 25\% sold vultures or their parts for consumption. Traders identified the following traits ascribed to vulture remains: treatment of epilepsy, insanity, stroke, ease of delivery in women, spiritual protection against witches and witchcraft, evil spirits, good luck (during gambling, money doubling, competition, contest), to stimulate walking in infants, and to gain supernatural powers. The head of vultures was said to be highly 
valued because of the belief in many that it possesses clairvoyant powers.

\section{$\underline{\text { Origin vulture parts and prices }}$}

The common species of vulture identified by the traditional medicine sellers were Hooded Vulture with $90 \%$ of parts $(n=565)$ attributed to this species, $7 \%$ to African Whitebacked Vulture, and 3\% to Lappetfaced Vulture. The origin of almost half of the vulture parts supplied to traders came from within Nigeria, the rest was gathered from other countries in the region (Table 3). The dominant technique of killing vultures by suppliers was intoxication using various "chemicals" (47\% of respondents); $16.7 \%$ of traders indicated that pesticides were most often used, notably the insecticide
Lindane (widely used on cocoa farms, vegetable farms, maize and marketed as Gammalin-20), and nicotine powder from tobacco was mentioned as the principal poison by $11.5 \%$ of respondents. Fourteen percent of traders were supplied by poachers that killed vultures using shotguns or traps. Traders estimated the cost of a vulture ten years ago at NGN 150250 (USD 0.95-1.60), and currently in the range of NGN 2000-3000 (USD 13-19) per vulture. However, the cost of parts required by herbalists varies with the demand and the severity of the ailment to be treated. For example, the cost of parts used for the treatment of insanity or epilepsy was estimated at NGN 10,000 (USD 64) by one trader.

Table 3: Origin of vultures or their parts offered for sale in northern Nigerian markets. The percentage of respondents $(n=113)$ indicating the principal source locality for their vulture parts is presented.

\begin{tabular}{lc}
\hline Country & Percentage \\
\hline Nigeria & 43.4 \\
Niger & 16.8 \\
Benin & 11.5 \\
Sudan & 8.0 \\
Cameroon & 7.1 \\
Chad & 4.4 \\
No response & 8.9 \\
\hline
\end{tabular}




\section{Discussion}

Our results showed that the trade in vulture parts is widely practised in northern Nigeria, where $93 \%$ of traditional medicine dealers had vultures, or their parts, on offer, with $15 \%$ of traders selling vulture heads or complete carcasses. Vulture harvesting for food was reported to have contributed importantly to the local extinction of vultures in Ivory Coast (Thiollay 2006) and Nigeria (Elgood et al. 1994, Rondeau \& Thiollay 2004), and our data indicated that a quarter of traditional medicine traders in northern Nigeria sold vulture-derived products for consumption. Such consumption may not be without risks, given the possibility of ingestion of pesticide residues and the occurrence of the highly pathogenic avian influenza subtype H5N1 in wild vulture populations in the region (Ducatez et al. 2007). The utilisation of vultures to treat a range of ailments, or for clairvoyant powers, intelligence, and good luck in northern Nigeria adds to observations of the use of vultures in traditional medicine in other parts of Nigeria (Adeola 1992, Sodeinde \& Soewu 1999, Nikolaus 2001, Soewu 2008), western Africa (Therasse \& Thauront 1988, Ntiamoa-Baidu 1987, Ogada \& Buij 2011), and southern Africa (e.g. Beilis \& Esterhuizen
2005, Mander et al. 2007). The use of vulture parts for traditional medicine seems accepted and practised across society, independent of social status or level of education, as seen elsewhere in Africa (Mander et al. 2007). Our surveys revealed that prices paid for vulture parts have risen, which is likely due to increased demand in the face of declining availability. This concurs with results by Nikolaus (2001) who mentioned a price of USD 10-20 for large vultures in Nigeria in 1999 but more recently, prices up to USD 100 per vulture in western Africa (Nikolaus 2011). Rising prices may stimulate Nigerian traders and hunters to source vultures from neighbouring countries, as already reported by Nikolaus (2001) and confirmed by our surveys. Indeed, vultures in neighbouring Cameroon are known to be targeted to supply the traditional medicine markets in Nigeria, with traders offering substantial amounts of money for vulture eggs (Ogada \& Buij 2011).

In Nigeria, Rüppell's Griffon, African White-backed Vulture, Lappet-faced Vulture, and Whiteheaded Vulture are now only rarely recorded and mostly inside protected areas (Tende \& Ottosson 2008, P. Hall in litt.). Of the 39 markets surveyed in our study, 21\% were 
within a distance of $11 \mathrm{~km}$ from a protected area, and poachers may have acquired large vultures mostly from these protected areas. This is supported by an arrest of a bushmeat dealer with vulture parts in Gashaka Gumti National Park in July 2011 (Y. Saidu pers. obs.). Large vulture species appear to have largely vanished from western African markets outside Nigeria (Nikolaus 2011), which apparently is the only country where people can still afford to buy such highly-valued species for traditional medicine purposes. Contrary to the large vultures, the ease of access to and relative abundance of Hooded Vultures, which are commonly associated with abattoirs and refuse dump areas in human settlements, may contribute to their vulnerability to poachers (Sodeinde \& Soewu 1999, Ogada \& Buij 2011). Hooded Vulture parts were commonly sold by the traditional medicine sellers in northern Nigeria, which agrees with earlier findings from the country (Adeola 1992, Sodeinde \& Soewu 1999, Nikolaus 2001). Outside Nigeria, Hooded Vultures have reportedly been used for traditional medicine or food in Ghana (NtiamoaBaidu 1987), Cameroon (Ogada \& Buij 2011), and Burkina Faso (Ducatez et al. 2007). Interestingly, the numbers of large vultures declined in two large Nigerian markets between 1999-2008, whereas the number of Hooded Vultures increased from three specimens in 1999 to 48 specimens in 2008 (Nikolaus 2011). Such increased demand for Hooded Vultures, possibly related to increased difficulty in obtaining the larger species and a shift to more easily obtained Hooded Vultures, might have contributed to the rapid disappearance of Hooded Vultures from towns and rural villages where they were formerly common (Rondeau \& Thiollay 2004).

Urgent steps are required to stop the unsustainable trading of vultures in Nigeria and between Nigeria and neighboring countries, which may actually have caused the virtual extinction of large vultures in Nigeria. The current levels of trade have the potential to exterminate remaining vulture populations in the region and possibly beyond. We propose the following:

1. An aggressive awareness campaign targeting hunters and traditional medicine dealers. In Nigeria, an awareness campaign targeting traditional medicinal dealers is likely to be effective since they can easily be reached and monitored in 
the markets by law enforcement officers;

2. Registration of traditional medicine traders to enable proper monitoring of their products on sale;

3. Education on the potential dangers of the consumption or utilisation of vultures, from exposure to avian influenza or pesticides toxic to man, and on the important ecological role of vultures with regard to waste disposal at primary and secondary schools;
4. Enhanced protection and vigilance with regard to potential vulture poaching in the National Parks and protected reserves located in the savanna region;

5. All vultures of countries in West and Central Africa should be uplisted to Appendix I of CITES to help implement conservation measures and strengthen the ability of conservation services to tackle the illegal trade.

Keywords: traditional medicine, vulture trade, northern Nigeria, conservation

\section{Acknowledgements}

The authors thank all merchants from the visited markets in the northern States for their collaboration. O.A. Okeyoyin is thanked for facilitating logistics. Y. Saidu thanks L. Bahaa-al-din and P. Henschel/Panthera for their support. K. Abakura, J. Mamza, A. Kikwashi, M. Dikko, M. Kimbian, G. Kargong, and K. Pepeh are thanked for their important contribution to data collection. We thank an anonymous referee for comments to the draft.

\section{References}

Adeola, M.O. 1992. Importance of wild animals and their parts in the culture, religious festivals and traditional medicine of Nigeria. Environmental Conservation 19: 125-134.

Beilis, N. \& Esterhuizen, J. 2005. The potential impact on Cape Griffon Gyps coprotheres populations due to the trade in traditional medicine in Maseru, Lesotho. Vulture News 53: 15-19. 
Cook, A.W. \& Mundy, P.J. 1980. Rüppell’s Griffon vulture at Kotorkoshi, Nigeria. Malimbus 2: 102-105.

Ducatez, M.F., Tarnagda, Z., Tahita, M.C., Sow, A., de Landtsheer, S., Londt, B.Z., Brown, I.H., Osterhaus, D.M., Fouchier, R.A., Ouedraogo, J.B. \& Muller, C.P. 2007. Genetic characterization of HPAI (H5N1) viruses from poultry and wild vultures, Burkina Faso. Emerging Infectious Diseases 13: 611-613.

Elgood, J.H., Heigham, J.B., Moore, A.M., Nason, A.M., Sharland, R.E. \& Skinner, N.J. 1994 The Birds of Nigeria. Checklist 4, 2nd ed., British Ornithologists' Union, Tring.

Ibrahim, J.A, Muazzam, I., Jegede, I.A. \& Kunle, O.F. 2010. Medicinal plants and animals sold by the "Yan-Shimfidas" of Sabo Wuse in Niger State, Nigeria. African Journal of Pharmacy and Pharmacology 4: 386-394.

Igoli, J.O., Igoli, O.G., Tor-Anyin, T.A. \& Igoli, N.P. 2005. Traditional Medicine Practice Amongst The Igede People of Nigeria Part II. African Journal of Traditional, Complementary and Alternative Medicines 2: 134152.

Mander, M., Diederichs, N., Ntuli, L., Mavundla, K., Williams, V. \& McKean, S. 2007. Survey of the trade in vultures for the traditional health industry in South Africa. FutureWorks Report for Ezemvelo KZN Wildlife. Pp. 1-54.

Nikolaus, G. 2001. Bird exploitation for traditional medicine in Nigeria. Malimbus 23: 45-55.

Nikolaus, G. 2011. The fetish culture in West Africa: An ancient tradition as a threat to endangered birdlife? In: Tropical vertebrates in a changing world, Schuchmann, K.-L. (Ed.). Bonner Zoologische Monographien, Zoologisches Forschungsmuseum Alexander Koenig, Bonn. Pp 145-151.

Ntiamoa-Baidu, Y. 1987. West African wildlife: a resource in jeopardy. Unasylva 39: 27-35.

Ogada, D.L. \& Buij, R. 2011. Decline of the Hooded Vulture Necrosyrtes monachus across its African range. Ostrich 82: 101-113.

Rondeau, G. \& Thiollay, J.-M. 2004. West African vulture decline. Vulture News 51: 13-31.

Sodeinde, S.O. \& Soewu, D.A. 1999. Pilot study of the traditional medicine trade in Nigeria. Traffic Bulletin 18: 35-40. 
Soewu, D.A. 2008. Wild Animals in ethnozoological practices among the Yorubas of southwestern Nigeria and the implications for biodiversity conservation. African Journal of Agricultural Research 3: 421-427.

Tende, T. \& Ottosson, U. 2008. The current status of vultures in Yankari. Vulture News 59: 7-12.

Terrasse, M., \& Thauront, M. 1988. The vultures of Mali. Vulture News 20: 47.

Thiollay, J.-M. 2001. Long-term changes of raptor populations in northern Cameroon. Journal of Raptor Research 35: 173-186.

Thiollay, J.-M. 2006. The decline of raptors in West Africa: long-term assessment and the role of protected areas. Ibis 148: 240-254.

Thiollay, J.-M. 2007. Raptor population decline in West Africa. Ostrich 78: 405-413. 
Appendix: Village markets in northern Nigeria where surveys were conducted.

\begin{tabular}{|c|c|}
\hline Village & Number of respondents \\
\hline Sabo & 2 \\
\hline Kaboji & 3 \\
\hline Mariga & 4 \\
\hline Wawa & 2 \\
\hline Woro & 1 \\
\hline Toungo & 3 \\
\hline Maje & 1 \\
\hline Diko & 6 \\
\hline Ngurore & 5 \\
\hline Garba Chede & 3 \\
\hline Jada & 5 \\
\hline Garbabu & 1 \\
\hline Karanti & 2 \\
\hline Yola & 4 \\
\hline Serti & 1 \\
\hline Gamu & 1 \\
\hline Timbokum & 2 \\
\hline Ganye & 4 \\
\hline Yeliso & 1 \\
\hline Jajimaji & 4 \\
\hline Nguru & 1 \\
\hline Garun Alkau & 2 \\
\hline Gashua & 5 \\
\hline Ngiru & 4 \\
\hline Kiri & 1 \\
\hline Banki & 5 \\
\hline Bama & 9 \\
\hline Maiduguri & 7 \\
\hline Dandume & 2 \\
\hline Gulumba & 2 \\
\hline Brinin Gwari & 6 \\
\hline Udawa & 3 \\
\hline Babon Layi & 1 \\
\hline Digare & 3 \\
\hline Tilde & 1 \\
\hline Toro & 1 \\
\hline Dandume & 2 \\
\hline Gumau & 1 \\
\hline Nguroje & 2 \\
\hline Total & 113 \\
\hline
\end{tabular}

$* * * * * *$ 